\title{
HUBUNGAN KARAKTERISTIK INOVASI DAN POLA KOMUNIKASI TERHADAP KEBERLANJUTAN PENERAPAN TEKNOLOGI PADI SALIBU DI KABUPATEN TANAH DATAR
}

\author{
(Relationship Between Innovation Characteristics and Communication Pattern \\ Towards the Sustainability of Salibu Technology Implementation in Tanah Datar \\ Regency)
}

\author{
Sri Wahyuni \\ Fakultas Pertanian Universitas Andalas, Padang 25163, Indonesia \\ Email korespondensi : sriwahyuni_unand@yahoo.co.id
}

Received: 18 October 2018; Revised: 26 May 2019; Accepted: 12 June 2019

\begin{abstract}
Abstrak
Penelitian ini bertujuan untuk: 1) mendeskripsikan karakteristik inovasi, pola komunikasi dan keberlanjutan penerapan teknologi salibu di Kabupaten Tanah Datar, dan 2) menganalisis hubungan karakteristik inovasi dan pola komunikasi terhadap keberlanjutan penerapan padi salibu di Kabupaten Tanah Datar. Penelitian ini dirancang secara kuantitatif menggunakan metode survei dan didukung data deskriptif kualitatif. Lokasi penelitian dipilih secara purposif berdasarkan topografi lokasi, yaitu di Kecamatan Pariangan dan Kecamatan Batipuh. Analisis data penelitian dilakukan dengan menggunakan analisis statitistik deskriptif dan statistik inferensia menggunakan software SPSS 23.00. Karakteristik inovasi teknologi salibu umumnya tergolong baik, dimana penerapan teknologi salibu di kedua daerah memiliki keuntungan relatif, sesuai dengan kebutuhan dan sumberdaya yang dimiliki petani, tidak rumit dan mudah dipraktikkan di lahan kecil, serta dapat diamati pertumbuhan dan hasilnya. Pola komunikasi para pelaku dalam menerapkan padi salibu sudah berlangsung baik, dimana tipe komunikasi yang diterapkan berlangsung dialogis dengan melibatkan partisipasi seluruh pelaku, arah komunikasi berlangsung ke segala arah (konvergen), frekuensi komunikasi sering dilakukan, dan kualitas komunikasi berlangsung baik di mana pelaku sama-sama memahami makna pesan yang disampaikan. Penerapan padi salibu di kedua daerah sudah berkelanjutan baik di setiap musim panen, pertambahan luas lahan, hingga keinginan untuk terus menerapkan dan mengembangkan teknologi salibu. Keberlanjutan tersebut didukung oleh karakteristik inovasi dan pola komunikasi di kedua daerah.
\end{abstract}

Kata kunci: karakteristik inovasi, keberlanjutan, pola komunikasi, teknologi salibu

\begin{abstract}
This research aims to describe innovation characteristics, communication pattern and the sustainability of Salibu technology implementation and to analyze the relationship between innovation characteristics, communication pattern and the sustainability in Tanah Datar Regency. The research is a survey method using quantitative and qualitative data and takes place in Pariangan and Batipuh sub-Districts. Data are analyzed using descriptive and inferential statistics using SPSS 23.00. Salibu innovation technology characteristics is categoryzed as good, namely the salibu implementation has a relative profit, meets farmers' needs, is easily applied and observed. Communication patterns of farmers in implementing the salibu is also good where communication is convergent, frequent, involving all participants. The implementation of salibu techonology is sustainable that is supported by innovation characteristics and two-way communication pattern
\end{abstract}

Keywords: innovation characteristics, communication pattern, sustainability, Salibu technology 


\section{PENDAHULUAN}

Indonesia menghadapi peningkatan kebutuhan bahan pangan seiring dengan laju pertumbuhan penduduk yang terus meningkat, sementara produksi dalam negeri belum mencukupi kebutuhan tersebut. Beras sebagai bahan makanan utama masyarakat Indonesia menjadi salah satu komoditas pangan yang mengalamai peningkatan permintaan. Balitbangtan (2015) mencatat bahwa terdapat indikasi laju pertumbuhan produksi padi semakin menurun dan biaya produksi per satuan luas semakin meningkat dalam lima tahun terakhir. Oleh karena itu, pencapaian target produksi padi ke depan akan semakin sulit. Pemerintah mencanangkan peningkatan produksi padi nasional sebesar $1,5 \%$ per tahun untuk mengatasi permasalahan tersebut. Oleh karena itu, upaya peningkatan produksi padi harus terus dilakukan melalui berbagai terobosan peningkatan produksi dan produktivitas (Balitbangtan, 2015; Dirjen Tanaman Pangan Kementan 2017).

Menyadari strategisnya komoditas beras tersebut, pemerintah terus berupaya untuk mewujudkan peningkatan produksi padi melalui berbagai cara seperti Gerakan Penerapan Pengelolaan Tanaman Terpadu (GPPTT) dan berbagai Upaya Khusus (Upsus) (Balitbangtan, 2015; Dirjen Tanaman Pangan Kementan, 2017). Indonesia memiliki berbagai jenis pola budidaya tanaman padi, baik berdasarkan temuan peneliti melalui eksperimen klinis, maupun temuan masyarakat berdasarkan hasil kearifan lokal setempat (local wisdom). Terdapat beragam pola budidaya yang berasal dari kebiasaan dan adat istiadat masyarakat setempat dan terbukti memiliki berbagai keuntungan, seperti pola tanam tumpang sari di Jawa Timur (Setiawan 2009), Kejrun Blang dan Kanuri Blang di Aceh (Ansor dan Nurbaiti, 2014; Maifianti et al. 2014; Putra et al. 2012), hingga budidaya padi salibu (salin ibu) di Sumatera Barat (Erdiman 2013).

Teknologi budidaya padi salibu, yang selanjutnya disebut dengan teknologi salibu. merupakan salah satu bentuk kearifan lokal masyarakat yang berkembang di Sumatera Barat, belakangan juga lebih dikenal dengan istilah padi ratun. Teknologi padi salibu adalah teknologi budidaya padi yang memanfaatkan batang bawah setelah panen sebagai penghasil tunas/anakan yang akan dipelihara. Tunas ini berfungsi sebagai pengganti bibir pada sistem tanam pindah (ta-pin) (Erdiman et al. 2013). Dengan dilatarbelakangi berbagai hal seperti kebutuhan beras nasional yang semakin meningkat, terjadinya alih fungsi lahan ke sektor non pertanian, hingga terbatasnya varietas unggul terutama di daratan tinggi dan terbatasnya teknologi budidaya padi (Erdiman et al. 2013), BPTP Solok kembali meneliti teknologi salibu pada tahun 2013 sebagai salah satu upaya pemerintah untuk mewujudkan swasembada beras 2015-2019 (RKT Kementan 2015).

Penelitian teknologi salibu kembali dilakukan karena memiliki potensi besar untuk dikembangkan karena memiliki berbagai keunggulan. Erdiman et al. (2013) menyebutkan bahwa beberapa keuntungan teknologi salibu antara lain adalah hemat dari segi biaya, hemat benih, hemat tenaga kerja, hemat air, dan ramah lingkungan. Teknologi salibu juga dapat meningkatkan produktivitas padi per unit area dan per unit waktu, dan meningkatkan indek panen dari sekali menjadi dua sampai tiga kali panen setahun. Jika dibandingkan dengan teknologi ratun konvensional, teknologi salibu mampu menghasilkan jumlah anakan yang lebih banyak dan seragam. Selain itu, produktivitas bisa sama bahkan lebih tinggi dari tanaman utamanya sehingga meningkatkan produksi setiap musim tanam. Penerapan budidaya padi salibu dengan memanfaatkan varietas berdaya hasil tinggi, tentu akan lebih menggairahkan aktivitas usahatani, karena dapat diperoleh tambahan hasil yang sangat nyata (Erdiman et al. 2013).

Sebagai inovasi teknologi yang berasal dari kearifan lokal setempat, budidaya salibu telah diluncurkan sebagai salah satu program pertanian dari kementerian pertanian. Berdasarkan Pedoman Pelaksanaan Kegiatan Padi 2017 dari Direktorat Jenderal Tanaman Pangan Kementrian Pertanian (2017), diketahui bahwa teknologi padi salibu diterapkan pada lahan seluas 10.000 hektar di seluruh Indonesia. Balitbangtan (2015) menyebutkan bahwa saat ini teknologi salibu telah dicoba di beberapa daerah di luar Sumatera Barat, seperti Jawa Timur, Kalimantan Selatan, Kalimantan Utara, Sulawesi Tengah, Sumatra Selatan, Riau, Aceh, Sumatera Utara, Bangka Belitung, Nusa Tenggara Barat, dan lain-lain.

Sumatera Barat sebagai daerah sentral pengembangan teknologi salibu juga telah menerapkan teknologi ini pada beberapa 
daerah, seperti Kabupaten Dharmasraya, Kabupaten Agam, Kabupaten Solok, Kota Padang Panjang, hingga Kabupaten Tanah Datar sebagai daerah penemu awal teknologi salibu. Keberlanjutan penerapan teknologi padi salibu sebagai salah satu bentuk inovasi teknologi berhubungan dengan berbagai faktor, baik faktor fisik dalam budidaya dan karakteristik inovasi teknologi salibu; maupun faktor nonfisik yang berhubungan dengan manusia, seperti karakteristik petani dan pola komunikasi. Berbagai penelitian sehubungan dengan karakteristik inovasi dan pola komunikasi terhadap penerapan inovasi teknologi telah banyak dilakukan, seperti pengaruh saluran komunikasi interpersonal terhadap adopsi inovasi pertanian bioindustri integrasi serai wangi-ternak (Rushendi et al. 2017), hubungan karakteristik petani dalam program SL-PTT (Narti 2015); pengaruh peran penyuluh terhadap adopsi inovasi padi sawah (Putra et al. 2012; Yanfika et al. 2019); efektifitas AKIS untuk diseminasi inovasi ISFM (integrated soil fertility management) di Kenya dan Ghana (Adolwa et al. 2016); serta penelitian mengenai model alternatif untuk memprediksi tingkat adopsi inovasi petani, dimana faktor yang menentukan percepatan adopsi teknologi adalah nilai atribut inovasi dan komunikasi interpersonal (Samiee dan RezaeiMoghaddam 2017; Listiana et al. 2019).

Meskipun demikian, penelitian yang berhubungan dengan teknologi salibu lebih banyak mengarah pada teknis budidaya yang merupakan faktor fisik, seperti penelitian yang dilakukan oleh Suwandi et al. (2012), Susilawati dan Purwoko (2012), Erdiman et al. (2013), Erdiman (2013), Ritonga (2015), Sinaga et al. (2015), dan Herlinda et al. (2015). Belum terdapat kajian mengenai faktor nonfisik teknologi salibu seperti karakteristik inovasi dan pola komunikasi untuk keberlanjutan penerapan teknologi salibu. Padahal, karakteristik inovasi dan pola komunikasi memiliki hubungan dan pengaruh terhadap keberlanjutan penerapan suatu inovasi, seperti hasil penelitian Mannan et al. (2017) dan Indraningsih (2011).

Oleh karena itu, secara umum penelitian ini bertujuan untuk menganalisis hubungan karakteristik inovasi dan pola komunikasi terhadap keberlanjutan penerapan teknologi salibu di Kabupaten Tanah Datar. Secara khusus, penelitian ini bertujuan untuk 1) mendeskripsikan karakteristik inovasi, pola komunikasi dan keberlanjutan penerapan teknologi salibu di Kabupaten Tanah Datar, dan 2) menganalisis hubungan karakteristik inovasi dan pola komunikasi terhadap keberlanjutan penerapan padi salibu di Kabupaten Tanah Datar.

\section{METODE PENELITIAN}

Penelitian dilaksanakan pada bulan Agustus hingga Oktober 2017 di Kabupaten Tanah Datar, Provinsi Sumatera Barat. Penentuan lokasi dilakukan dengan purposif, dengan alasan Kabupaten Tanah Datar merupakan salah satu daerah sentra produksi padi dan telah mengembangkan Teknologi Padi Salibu di Provinsi Sumatera Barat. Sampel untuk penelitian ini dipilih secara multistage random sampling yang didasarkan pada topografi dan geografis lokasi. Kelompok Wanita Tani Flamboyan di Kecamatan Pariangan sebagai sampel pada lokasi di daratan tinggi dan Kelompok Tani Beringin Bersatu di Kecamatan Batipuh sebagai sampel pada lokasi di daratan rendah.

Populasi penelitian adalah petani yang telah menerapkan teknologi padi salibu di kecamatan terpilih di Kabupaten Tanah Datar. Pengambilan sampel dilakukan secara sensus, yaitu 51 orang di Kelompok Wanita Tani Flamboyan Kecamatan Pariangan dan 51 orang di Kelompok Tani Beringin Bersatu Kecamatan Batipuh. Analisa data dilakukan menggunakan uji statistik deskriptif dan uji statistik inferensia. Uji statistik inferensia menggunakan analisis korelasi rank Spearman dengan bantuan SPSS 21.00 .

\section{HASIL DAN PEMBAHASAN}

\section{Karakteristik Inovasi Padi Salibu di Kecamatan Pariangan dan Kecamatan Batipuh Kabupaten Tanah Datar}

Salah satu faktor yang memengaruhi proses pengambilan keputusan dan kecepatan adopsi inovasi adalah sifat atau karakteristik inovasi itu sendiri, seperti halnya yang disebutkan oleh Rogers (2003) dan ditegaskan oleh beberapa hasil penelitian seperti Meulen et al. (2016), Senyolo et al. (2017) dan Suryani et al. (2017). Karakteristik inovasi tersebut yang terdiri atas: (1) keuntungan relatif (relative advantage); (2) kesesuaian (compatibility); (3) kerumitan (complexity); (4) kemungkinan 
dicoba (trialability); dan (5) kemungkinan diamati (observability).

Berdasarkan uji beda mann-whitney, terdapat beda nyata pada taraf $\mathrm{p}<0,05$ antara indikator karakteristik inovasi yang terdiri atas keuntungan relatif, tingkat kesesuaian, tingkat kemudahan, dan tingkat keteramatan inovasi di Kecamatan Pariangan dan Kecamatan Batipuh. Umumnya karakteristik inovasi teknologi salibu di Pariangan dan Batipuh pada umumnya serupa. Keuntungan relatif padi salibu di kedua kecamatan tergolong tinggi, artinya petani mendapatkan manfaat dan keuntungan atas penerapan padi salibu. Keuntungan yang didapatkan oleh petani antara lain hemat biaya produksi, hemat biaya benih, hemat tenaga kerja, dan hemat dalam penggunaan air. Selain itu, keuntungan lainnya adalah bertambahnya hasil produksi rata-rata 25 persen dan indek panen bertambah menjadi tiga kali dalam setahun, dimana hasil temuan di lapangan tersebut sejalan dengan Erdiman et al. (2013) dan Erdiman (2013). Keuntungan relatif tersebut juga memengaruhi keputusan petani menerapkan teknologi salibu, sebagaimana hasil penelitian Sholahuddin et al. (2017) bahwa keuntungan relatif memengaruhi adopsi inovasi.

Inovasi yang sesuai merupakan inovasi mudah yang diadaptasi oleh masyarakat (Mulyadi et al. 2009). Hasil penelitian menunjukkan bahwa tingkat kesesuaian teknologi salibu di Kecamatan Pariangan dan Kecamatan Batipuh sesuai dengan kebutuhan, kebiasaan, sumberdaya, serta keadaan lingkungan petani di Pariangan dan Batipuh. Berdasarkan observasi di lapangan, hal ini salah satunya disebabkan karena padi salibu merupakan teknologi yang berasal dari kebiasaan daerah setempat, sebagaimana yang juga dijelaskan oleh Balitbangtan (2015) bahwa teknologi budidaya padi salibu merupakan budidaya padi spesifik lokasi berbasis kearifan lokal.

Petani di Kecamatan Pariangan dan Kecamatan Batipuh menilai bahwa teknologi salibu tidak rumit dan tidak sulit, baik pemahaman secara teori, praktik, maupun akses terhadap sumberdaya yang dibutuhkan. Penerapan teknologi padi salibu di kedua kecamatan relatif mudah dilakukan oleh petani, baik dalam luar lahan skala kecil maupun skala besar. Petani juga dapat dengan mudah mengamati tingkat pertumbuhan, hasil, hingga peningkatan produksi padi yang menggunakan teknologi salibu dengan mudah. Berdasarkan temuan di lapangan, kemudahan petani dalam mengamati pertumbuhan dan hasil teknologi salibu tersebut juga menjadi salah satu motivasi petani dalam menerapkan padi salibu, sebagaimana yang juga dinyatakan oleh Sholahuddin et al. (2017) bahwa tingkat keteramatan (observability) memengaruhi adopsi inovasi.

\section{Pola Komunikasi Teknologi Salibu di Kecamatan Pariangan dan Kecamatan Batipuh Kabupaten Tanah Datar}

Pola komunikasi merupakan standirisasi pola tingkah laku yang berfungsi sebagai model dan selalu mengikuti alur tertentu. Pola komunikasi berperan dalam berbagai program dan kegiatan pembangunan pertanian. Berbagai pola komunikasi diterapkankan guna percepatan penerapan suatu inovasi teknologi baru oleh petani. Dalam pelaksanaannya, polapola komunikasi tersebut berpengaruh dalam pelaksanaan kegiatan pembangunan pertanian termasuk penerapan suatu program dan inovasi. Berbagai penelitian menunjukkan bahwa komunikasi memiliki peran penting dan strategis dalam penerapan program atau inovasi di bidang pertanian, seperti halnya hasil penelitian oleh Musyafak dan Ibrahim (2005), Satriani et al. (2011), Zainal et al. (2014), Muchtar et al. (2014), Muchtar (2016), dan Darmastuti et al. (2016).

Pola komunikasi petani dalam penerapan teknologi salibu di Kecamatan Pariangan dan Kecamatan Batipuh tergolong tinggi, artinya pola komunikasi yang terjadi di kedua daerah sudah berlangsung secara partisipatif dengan mengandalkan keterlibatan seluruh pelaku yang terlibat, terutama petani dan penyuluh. Tipe komunikasi dan arah komunikasi yang terjadi di kedua daerah umumnya tergolong tinggi, artinya komunikasi yang berlangsung antara pelaku yang terlibat seperti petani dan penyuluh berlangsung secara timbal balik. Komunikasi yang berlangsung antara petani dan penyuluh tidak lagi berlangsung secara satu arah (topdown), melainkan sudah dua arah (bottom-up). Hal ini mendorong peningkatan motivasi petani untuk menerapkan inovasi, sebab arus informasi berlangsung ke segala arah dimana petani dapat saling berbagi informasi mengenai kebutuhannya atas penerapan teknologi salibu kepada sesama petani maupun kepada penyuluh, seperti halnya hasil temuan Satriani 
et al. (2011) dan Muchtar et al. (2014). Firmansyah et al. (2017) juga menegaskan hal serupa bahwa untuk mendorong percepatan adopsi inovasi, perlu menggunakan strategi komunikasi yang melibatkan seluruh pelaku dalam setiap kegiatan.

Frekuensi komunikasi di kedua daerah tergolong tinggi. Hal ini disebabkan karena baik petani di Pariangan maupun di Batipuh sama-sama antusias dalam penerapan teknologi salibu. Terutama di Pariangan yang memang sudah menjadi sentra teknologi salibu, petani bahkan aktif dalam berbagi dan mencari informasi secara mandiri, baik kepada sesama penyuluh hingga kepada peneliti yang melakukan penelitian di daerah tersebut. Penyuluh juga aktif mengunjungi petani, baik saat ada kegiatan khusus, maupun di hari-hari biasa. Informasi mengenai teknologi salibu pun tidak hanya didapatkan petani saat ada kegiatan khusus seperti sekolah lapang, akan tetapi di waktu-waktu tidak formal seperti ketika penyuluh mengunjungi petani untuk sekedar bercengkrama, berbagi cerita, dan sebagainya. Tingginya frekuensi komunikasi menjadi salah satu pendorong baiknya kualitas komunikasi yang didapatkan oleh petani. Petani di kedua daerah menjadi memahami informasi-informasi terkait penerapan salibu yang didapatkan baik dari sesama petani mapun dari penyuluh. Hal ini dapat mendorong adopsi hingga keberlanjutan penerapan teknologi salibu oleh petani, sejalan dengan penelitian Wibowo et al. (2012) dan Pamungkas et al. (2013) bahwa frekuensi komunikasi dapat mendorong penerapan inovasi oleh petani.

\section{Keberlanjutan Penerapan Teknologi Salibu di Kecamatan Pariangan dan Kecamatan Batipuh Kabupaten Tanah Datar}

Keberlanjutan penerapan teknologi salibu oleh petani umumnya didorong oleh berbagai keuntungan yang didapatkankan, seperti hemat dari segi biaya, waktu dan tenaga kerja, serta dapat menambah jumlah produksi dan indek panen, seperti halnya yang juga dijelaskan oleh Erdiman (2013). Namun, masih terdapat beberapa petani di Kecamatan Batipuh yang tidak menerapkan padi salibu secara berkelanjutan. Berdasarkan wawancara dengan responden di Batipuh, terdapat kekurangan air irigasi di musim kemarau karena meskipun padi salibu tidak membutuhkan air yang terlaluu banyak, akan tetapi jumlahnya harus tetap diatur agar tidak kering. Selain itu, pengelolaan padi salibu yang kurang optimal juga mengakibatkan produksi padi yang dihasilkan oleh petani mengalami penurunan, sehingga pada musim tanam berikutnya beberapa petani tidak melanjutkan penerapan padi salibu.

Selanjutnya, tingkat keberlanjutan penggunaan lahan untuk penerapan padi salibu di kedua kecamatan tergolong tinggi. Demikian juga halnya untuk keberlanjutan dalam penggunaan lahan. Adapun petani yang tidak menambah luas lahannya untuk penerapan padi salibu, terutama di Batipuh, disebabkan oleh capaian kebutuhan air irigasi padi yang tidak mencukupi untuk teknologi salibu, sehingga beberapa luas lahan sawah diolah dengan menggunakan teknik budidaya padi konvensional.

\section{Hubungan Karakteristik Inovasi dan Pola Komunikasi dengan Keberlanjutan Penerapan Teknologi Padi Salibu di Kecamatan Kecamatan Pariangan dan Kecamatan Batipuh Kabupaten Tanah Datar}

Keputusan individu untuk menerapkan suatu inovasi dipengaruhi oleh beberapa hal, yaitu: (1) karakteristik individu, (2) karakteristik sosial ekonomi, dan (3) kekuatan penerimaan antas kebutuhan inovasi. Selanjutnya, salah satu faktor yang memengaruhi proses pengambilan keputusan dan kecepatan adopsi inovasi adalah sifat atau karakteristik inovasi itu sendiri, yaitu: (1) keuntungan relatif (relative advantage); (2) kesesuaian (compatibility); (3) kerumitan (complexity); (4) kemungkinan dicoba (trialability); dan (5) kemungkinan diamati (observability) (Rogers 2003 dan Suryani et al. 2017).

Berbagai literatur dan hasil penelitian seperti yang dikemukakan oleh Rogers (2013), Meulen et al. (2016), dan Senyolo et al. (2017) menunjukkan bahwa karakteristik inovasi berpengaruh terhadap penerapan inovasi. Berbagai karakteristik inovasi tersebut dapat mendorong kecepatan adopsi inovasi, akan tetapi juga dapat menghambat adopsi inovasi seperti halnya temuan oleh Warnaen et al. (2013). Berdasarkan analisa rank Spearman umumnya terdapat hubungan nyata pada taraf $\mathrm{p}<0,05$ antara karakteristik inovasi dengan keberlanjutan penerapan teknologi salibu baik 
di Kecamatan Pariangan maupun Kecamatan Batipuh. Tabel 1 memperlihatkan terdapat hubungan nyata pada taraf $\mathrm{p}<0,05$ antara setiap indikator karakteristik inovasi dengan keberlanjutan penerapan teknologi salibu di setiap musim tanam dan keberlanjutan pengembangan padi salibu di Pariangan. Hasil tersebut menunjukkan bahwa semakin bagus karakteristik inovasi teknologi salibu, maka keberlanjutan petani dalam menerapkan dan mengembangkan padi salibu semakin tinggi. Hal tersebut sejalan dengan hasil penelitian Suryani et al. (2017) bahwa karakteristik inovasi seperti keuntungan relatif, tingkat kesesuaian, dan tingkat kerumitan inovasi berpengaruh terhadap keberlanjutan petani dalam menerapkan suatu inovasi.

Tabel 1. Nilai Koefisien hubungan Karakteristik Inovasi dengan Keberlanjutan Penerapan Teknologi Padi Salibu

\begin{tabular}{|c|c|c|c|c|c|c|c|c|c|c|}
\hline \multirow{2}{*}{ Karakteristik Inovasi } & \multicolumn{2}{|c|}{$\begin{array}{l}\text { Penerapan padi } \\
\text { salibu setiap } \\
\text { musim tanam }\end{array}$} & \multicolumn{2}{|c|}{ Penggunaan lahan } & \multicolumn{2}{|c|}{$\begin{array}{c}\text { Pertambahan luas } \\
\text { lahan }\end{array}$} & \multicolumn{2}{|c|}{$\begin{array}{l}\text { Keberlanjutan } \\
\text { penerapan padi } \\
\text { salibu }\end{array}$} & \multicolumn{2}{|c|}{$\begin{array}{c}\text { Pengembangan } \\
\text { padi salibu }\end{array}$} \\
\hline & $\begin{array}{l}\text { Paria- } \\
\text { ngan }\end{array}$ & $\begin{array}{l}\text { Batip } \\
\text { uh }\end{array}$ & $\begin{array}{c}\text { Paria- } \\
\text { ngan }\end{array}$ & $\begin{array}{l}\text { Bati- } \\
\text { puh }\end{array}$ & $\begin{array}{l}\text { Paria- } \\
\text { ngan }\end{array}$ & $\begin{array}{c}\text { Bati- } \\
\text { puh }\end{array}$ & $\begin{array}{l}\text { Paria- } \\
\text { ngan }\end{array}$ & $\begin{array}{l}\text { Bati- } \\
\text { puh }\end{array}$ & $\begin{array}{l}\text { Pariang } \\
\text { an }\end{array}$ & $\begin{array}{l}\text { Bati- } \\
\text { puh }\end{array}$ \\
\hline 1. Keuntungan relatif & 271 &,- 013 &, $440 * *$ & ,052 & $445 * *$ &,- 101 &, $668 * *$ &,- 065 &, $668 * *$ &,- 103 \\
\hline $\begin{array}{l}\text { 2. Tingkat } \\
\text { Kesesuaian }\end{array}$ &, $282 *$ &, 126 &, $514 * *$ &, 264 &, $521 * *$ &, $345^{*}$ &, $750 * *$ & 049 &, $750 * *$ &,- 115 \\
\hline $\begin{array}{l}\text { 3. Tingkat } \\
\text { Kerumitan Inovasi }\end{array}$ &, $328^{*}$ &, $324 *$ &, $512 * *$ & ,290* &, $518 * *$ & ,237 &, $764^{* * *}$ &, 188 &, $764 * *$ &,- 057 \\
\hline $\begin{array}{l}\text { 4. Tingkat } \\
\text { Kemudahan }\end{array}$ &, $387 * *$ & ,196 &, $622^{* *}$ &, $320^{*}$ &, $629 * *$ & ,202 &, $903 * *$ &, $429 * *$ &, $903 * *$ & ,266 \\
\hline $\begin{array}{l}\text { 5. Tingkat } \\
\text { Keteramatan } \\
\text { Inovasi }\end{array}$ & ,328* & ,237 &, $512 * *$ &, 011 &, $518 * *$ &, 172 &, $764 * *$ & ,066 &, $764 * *$ &, 013 \\
\hline
\end{tabular}

Edwina dan Maharani (2010), Sadikin (2013), Fachrista dan Sarwendah (2014), dan Sholahuddin et al. (2017) juga menegaskan bahwa semakin menguntungkan inovasi, semakin mudah suatu inovasi diterapkan dan diamati, serta semakin sesuai inovasi tersebut bagi kebutuhan petani, maka akan semakin mudah pula petani mengadopsi suatu inovasi. Selanjutnya, Tabel 1 juga menunjukkan bahwa tingkat kemudahan inovasi padi salibu juga berhubungan nyata pada taraf $\mathrm{p}<0.05$ dengan keberlanjutan penggunaan lahan dan keberlanjutan penerapan padi salibu di Kecamatan Pariangan dan Kecamatan Batipuh. Berdasarkan observasi di kedua kecamatan, kemudahan penerapan teknologi padi salibu mendorong keberlanjutan penggunaan lahan dan penerapan padi salibu oleh petani. Seperti halnya yang disebutkan oleh Erdiman (2013), kemudahan tersebut salah satunya terlihat dari petani tidak lagi perlu melakukan pembenihan dan pembajakan dalam budidaya padi salibu

Pola komunikasi yang baik, dimana komunikasi antara para pelaku terjadi secara dialogis dan timbal balik, serta seluruh didorong partisipasinya dalam berkomunikasi, terbukti berpengaruh terhadap keberhasilan pelaksanaan program pertanian. Hal ini ditegaskan oleh berbagai penelitian oleh Muchtar et al. (2014), Darmastuti et al. (2017), Rushendi et al. (2017) dan Sukmayanto et al, (2019). . Terdapat hubungan nyata pada taraf $\mathrm{p}<0,05$ antara pola komunikasi dengan keberlanjutan penerapan teknologi salibu di Batipuh dan Pariangan. Terutama di Batipuh, tipe komunikasi, arah komunikasi, frekuensi komunikasi, dan kualitas komunikasi berhubungan dengan keberlanjutan penerapan teknologi salibu. Hal ini berarti, semakin baik pola komunikasi yang terjadi, semakin dialogis dan semakin sering para pelaku berkomunikasi, dan semakin paham dan mengerti para pelaku dengan informasi yang diberikan, maka penerapan padi salibu di kedua daerah akan semakin berlanjut pada setiap musim tanamnya. 
Tabel 2. Nilai Koefisien hubungan Pola Komunikasi dengan Keberlanjutan Penerapan Teknologi Padi Salibu

\begin{tabular}{|c|c|c|c|c|c|c|c|c|c|c|c|}
\hline & \multirow{2}{*}{ Pola Komunikasi } & \multicolumn{2}{|c|}{$\begin{array}{c}\text { Penerapan padi } \\
\text { salibu setiap musim } \\
\text { tanam }\end{array}$} & \multicolumn{2}{|c|}{ Penggunaan lahan } & \multicolumn{2}{|c|}{$\begin{array}{c}\text { Pertambahan luas } \\
\text { lahan }\end{array}$} & \multicolumn{2}{|c|}{$\begin{array}{l}\text { Keberlanjutan } \\
\text { penerapan padi } \\
\text { salibu }\end{array}$} & \multicolumn{2}{|c|}{$\begin{array}{c}\text { Pengembangan } \\
\text { padi salibu }\end{array}$} \\
\hline & & $\begin{array}{l}\text { Paria- } \\
\text { ngan }\end{array}$ & Batipuh & $\begin{array}{c}\text { Paria- } \\
\text { ngan }\end{array}$ & $\begin{array}{l}\text { Bati- } \\
\text { puh }\end{array}$ & $\begin{array}{c}\text { Paria- } \\
\text { ngan }\end{array}$ & $\underset{\mathrm{h}}{\text { Batipu }}$ & $\begin{array}{l}\text { Paria- } \\
\text { ngan }\end{array}$ & $\begin{array}{l}\text { Bati- } \\
\text { puh }\end{array}$ & $\begin{array}{l}\text { Paria- } \\
\text { ngan }\end{array}$ & $\begin{array}{l}\text { Bati- } \\
\text { puh }\end{array}$ \\
\hline 1. & Tipe komunikasi &, $280 *$ & ,298* &, 221 &, $484 * *$ & ,208 &, $489 * *$ &, $338^{*}$ &, $724 * *$ &, $412 * *$ &, $724 * *$ \\
\hline 2. & Arah komunikasi &, $419^{* *}$ &, $387 * *$ & ,096 &, $433^{* *}$ &,- 137 &, $422 * *$ &, $295^{*}$ &, $698 * *$ &, $371 * *$ &, $698^{* * *}$ \\
\hline 3. & $\begin{array}{l}\text { Frekuensi } \\
\text { komunikasi }\end{array}$ & 081 & ,298* &, 220 &, $484 * *$ &, 076 &, $489 * *$ &, $353^{*}$ &, $724 * *$ & ,266 &, $724 * *$ \\
\hline 4. & $\begin{array}{l}\text { Kualitas } \\
\text { komunikasi }\end{array}$ &, $329 *$ &, $286^{*}$ & , 129 &, $433^{* *}$ &, 184 &, $438 * *$ &, $544 * *$ &, $668 * *$ &, $386 * *$ &, $668^{* * *}$ \\
\hline
\end{tabular}

\section{KESIMPULAN}

Karakteristik petani teknologi salibu umumnya berusia 30->50 tahun, memiliki tingkat pendidikan formal SMP hingga perguruan tinggi, pendidikan non formal terkait penerapan teknologi salibu sebanyak 2 kali sejak tahun 2014, memiliki pengalaman berusahatani 1-6 tahun, tingkat pendapatan rendah hingga sedang, umumnya berstatus sebagai anggota di dalam kelompok dan masyarakat biasa dalam tatanan masyarakat, status lahan usaha tani umumnya sewa dan milik sendiri, serta luas lahan umumnya 0,5 hektar. Karakteristik inovasi teknologi salibu umumnya tergolong baik, dimana penerapan teknologi salibu di kedua daerah memiliki keuntungan relatif, sesuai dengan kebutuhan dan sumberdaya yang dimiliki petani, tidak rumit dan mudah dipraktikkan di lahan kecil, serta dapat diamati pertumbuhan dan hasilnya. Pola komunikasi para pelaku dalam menerapkan padi salibu sudah berlangsung baik, dimana tipe komunikasi yang diterapkan berlangsung dialogis dengan melibatkan partisipasi seluruh pelaku, arah komunikasi berlangsung ke segala arah (konvergen), frekuensi komunikasi sering dilakukan, dan kualitas komunikasi berlangsung baik di mana pelaku sama-sama memahami makna pesan yang disampaikan.

Penerapan padi salibu di kedua daerah sudah berkelanjutan baik di setiap musim panen, pertambahan luas lahan, hingga keinginan untuk terus menerapkan dan mengembangkan teknologi salibu. Keberlanjutan di kedua daerah didukung oleh karakteristik inovasi yang terdiri atas (1) keuntungan relatif (relative advantage); (2) kesesuaian (compatibility); (3) kerumitan (complexity); (4) kemungkinan dicoba (trialability); dan (5) kemungkinan diamati (observability); dan pola komunikasi yang terdiri atas (1) frekuensi komunikasi, (2) arah komunikasi, (3) tipe komunikasi, dan (4) kualitas komunikasi.

\section{DAFTAR PUSTAKA}

Adolwa IS, Schwarze IS, Belwood-Howard I, Schareika N, Buerkert. 2016. A Comparative Analysis of Agricultural Knowledge And Innovation Systems in Kenya And Ghana: Sustainable Agricultural Intensification in The RuralUrban Interface. Agriculture and Human Values 34(2): 453-472.

Ansor M, Nurbaiti. 2014. Relasi Gender Dalam Ritual Kenduri Blang pada Masyarakat Petani di Gampong Sukarejo Langsa. AtTafkir 7(1): 48-66.

[Balitbangtan] Balai Penelitian dan Pengembangan Pertanian. 2015. Panduan Teknologi Budidaya Padi Salibu. Jakarta: Kementerian Pertanian.

[Dirjen Tanaman Pangan] Direktorat Jenderal Tanaman Pangan. 2017. Pedoman Pelaksanaan Kegiatan Padi 2017. Jakarta: Kementerian Pertanian.

Darmastuti R, Bajari A, Martodirdjo HS, Maryani E. 2016. Gethok tular, pola komunikasi gerakan sosial berbasis kearifan lokal masyarakat samin di Sukolilo Jurnal ASPIKOM. 3(1): 104-118.

Edwina S. dan Maharani T. 2010. Persepsi Petani terhadap Inovasi Teknologi Pengolahan Pakan Ternak di Kecamatan Kerinci Kanan Kabupaten Siak. Indonesian Journal of Agriculture Economis. 2 : 170-183

Erdiman. 2013. Teknologi Salibu Meningkatkan Produktivitas Lahan (3-6 
Ton/Ha/Tahun) dan Pendapatan Petani (Rp.15-25 Juta/Tahun). Balai Pengkajian Teknologi Pertanian Sumatera Barat. Nieldanina, Misran. 2013. Inovasi Teknologi Salibu Meningkatkan Produktivitas Lahan, Mendukung Swasembada Pangan Berkelanjutan. Balai Pengkajian Teknologi Pertanian Sumatera Barat.

Fachrista IA, Sarwendah M. 2014. Persepsi dan Tingkat Adopsi Petani Terhadap Inovasi Teknologi Pengelolaan Tanaman Terpadu Padi Sawah. Agriekonomika. 3(1): 1-10.

Firmansyah H, Yulianti M, Alif M. 2017. Strategi komunikasi dalam penguatan kapasitas kelembagaan pada pengelolaan lahan gambut melalui peningkatan sumberdaya manusia di sektor pertanian Kalimantan Selatan. Journal of communication studies. 2(1): 119-131.

Herlinda S, Dewi R, Adam T, Suwandi, Wijaya A. 2015. Struktur komunitas laba-laba di ekosistem padi ratun: pengaruh aplikasi Beauveria bassiana (Balsamo). Jurnal Entomologi Indonesia. 12(2): 91-99.

Ilori AB, Lawal AF, Oke S. 2017. Effect of Socio-Economics Characteristics, Production and Innovation Capabilities on the Performance of Palm Kernel Processing Firms in South-western Nigeria. IJERMT. 6(1): 88-95.

Listiana, I. Efendi, I. Mutolib, A. dan Rahmat, A. 2019. The behavior of Extension Agents in Utilizing Information and Technology to Improve the Performance of Extension Agents in Lampung Province. Journal of Physics: Conference Series, 1155 (012004): 1-9.

Mannan S, Nordin SM, Rafik-Galea S, Rizal ARA. 2017. The Ironies of New Innovation and The Sunset Industry: Diffusion and Adoption. Journal of Rural Studies 55:316-322. DOI: https://doi.org/ 10.1016/j.jrurstud.2017.07.015.

Maifianti KS, Sarwoprasodjo S, Susanto D. 2014. Komunikasi Ritual Kanuri Blang sebagai Bentuk Kebersamaan Masyarakat Tani Kecamatan Samatiga Kabupaten Aceh Barat Propinsi Aceh. Jurnal Komunikasi Pembangunan. 12(2): 30-35.

Meulen HVD, Assseldonk MV, Ge L. 2016. Adoption of Innovation in European Agriculture.
Muchtar K. 2016. Penerapan Komunikasi Partisipatif pada Pembangunan di Indonesia. Jurnal Makna. 1(1): 20-32. , Purnaningsih N, Susanto D. 2014. Komunikasi Partisipatif pada Sekolah Lapangan Pengelolaan Tanaman Terpadu (SL-PTT). Jurnal Komunikasi Pembangunan. 12(2): 1-14.

Musyafak A, Ibrahim TM. 2005. Strategi percepatan adopsi dan difusi inovasi pertanian mendukung prima tani. Jurnal Analisis Kebijakan Pertanian. 3(1): 20-37.

Narti S. 2015. Hubungan Karakteristik Petani dengan Efektivitas Komunikasi Penyuluhan Pertanian dalam Program SLPTT. Jurnal Professional FIS UNIVED 2(2): 40-52.

Putra AWS, Hariadi SS, Harsoyo. 2012. Pengaruh Peran Penyuluh dan Kearifan Lokal terhadap Adopsi Inovasi Padi Sawah di Kecamatan Montasik Kabupaten Aceh Besar. KANAL. 1(1): 85-101.

[RKT Kementan] Rencana Kerja Tahunan Kementrian Pertanian. 2014. Rencana Kerja Tahunan Kementrian Pertanian Tahun 2015. Jakarta: Kementerian Pertanian.

Ritonga ES. 2015. Uji Adaptasi Galur - Galur Padi Ratun Di Lahan Pasang Surut Kabupaten Pelalawan Provinsi Riau. Prosiding Seminar Nasional Lahan Suboptimal.

Rogers E. 2003. Diffusion of Innovations Fifth Edition. New York (AS): The Free Pr.

Rushendi, Sarwoprasodjo S, Mulyandari RSH. 2016. Pengaruh Saluran Komunikasi Interpersonal terhadap Keputusan Adopsi Inovasi Pertanian Bioindustri Integrasi Serai Wangi-Ternak di Provinsi Jawa Barat. JAE 34(2): 135-144. DOI: http://dx.doi.org/ 10.21082/jae.v34n2.2016.135-144

Pamungkas S, Saleh A, Muljono P. 2013. Hubungan Aktivitas Komunikasi dengan Tingkat Keberdayaan Kader Posdaya di Kota dan Kabupaten Bogor. Jurnal Komunikasi Pembangunan. 11(1): 47-57.

Sadikin I. 2013. Pengaruh Faktor Sosial Ekonomi Terhadap Adopsi PTT di Sentra Padi Jawa Barat. Agros. 15(1): 123-136.

Samiee S, Rezei-Moghaddam K. 2017. The Proposed Alternative Model to Predict Adoption of Innovations: The Case of NoTill Technology in Iran. Journal of the 
Saudi Society of Agricultural Sciences 16(3): 270-279.

Satriani I, Muljono P, Lumintang RWE. 2011. Komunikasi Partisipatif pada Program Pos Pemberdayaan Keluarga (Studi Kasus di RW 05 Kelurahan Situgede, Kecamatan Bogor Barat, Kota Bogor). Jurnal Komunikasi Pembangunan. 9(2): 17-27.

Senyolo MP, Long TB, Blok V, Omta O. 2017. How the characteristics of innovations impact their adoption: An exploration of climate-smart agricultural innovations in South Africa. Journal of Cleaner Production. 30: 1-16.

Setiawan E. 2009. Kearifan Lokal Pola Tanam Tumpangsari di Jawa Timur. Agrovigor 2(2): 79-89.

Sholahuddin, Setyawan AA, Trisnawati R. 2017. Pengaruh Karakteristik Inovasi terhadap Niat Mengadopsi Solopos Epaper. Prosiding Semnas Riset Manajemen \& Bisnis. 63-84.

Sinaga PH, Trikoesoemaningtyas, Sopandie D, Aswidinnoor H. 2015. Daya Hasil dan Stabilitas Ratun Galur Padi pada Lahan Pasang Surut. Penelitian Pertanian Tanaman Pangan. 34(2): 97-104.

Sukmayanto, M. Alviana, ED. dan Mutolib, A. 2019. Persepsi Petani Padi Terhadap Program Billing Sistem Di Kecamatan Metro Barat Kota Metro. Mimbar Agribisnis: Jurnal Pemikiran Masyarakat Ilmiah Berwawasan Agribisnis. 5(1): 114123.

Suryani A, Fatchiya A, Susanto D. 2017. Keberlanjutan Penerapan Teknologi Pengelolaan Pekarangan oleh Wanita Tani di Kabupaten Kuningan. Jurnal Penyuluhan. 13(1): 50-63.

Susilawati, Purwoko BS. 2012. Pengujian Varietas dan Dosis Pupuk untuk
Meningkatkan Pertumbuhan dan Hasil Ratun-Padi di Sawah Pasang Surut. Jurnal Pengkajian dan Pengembangan Teknologi Pertanian. 15(1): 47-54.

Suwandi, Ammar M, Irsan C. 2012. Aplikasi Ekstrak Kompos Meningkatkan Hasil dan Menekan Penyakit Padi Sistem Ratun di Sawah Pasang Surut Kabupaten Banyuasin. Jurnal Lahan Suboptimal. 1(2): 116-122.

Warnaen A, Cangara H, Bulkis S. 2013. Faktor-Faktor yang Menghambat Inovasi pada Komunitas Petani dan Nelayan dalam Meningkatkan Kesejahteraan Masyarakat di Kabupaten Takalar. KAREBA. 2(3): 241-249.

Wibowo CT, Sumardjo, Hafidhuddin D, Agung SS. 2012. Pola Komunikasi pada Pengembangan Kapasitas Kewirausahaan Petani Sayuran (Kasus Pendampingan Misi Teknik Taiwan di Kabupaten Boyolali dan Bogor). Jurnal Komunikasi Pembangunan. 10(1): 47-57.

Yanfika, H. Listiana, I. Mutolib, A. dan Rahmat, A. 2019. Linkages between Extension Institutions and Stakeholders in the Development of Sustainable Fisheries in Lampung Province. Journal of Physics: Conference Series, 1155 (01201): 1-9.

Zainura U, Kusnadi N, Burhanuddin. 2016. Perilaku Kewirausahaan Petani Kopi Arabika Gayo di Kabupaten Bener Meriah Provinsi Aceh. Jurnal Penyuluhan 12(2): 126-143.

Zainal M, Lubis DP, Rangkuti PA. 2014. Pola komunikasi partisipatif pada program pengembangan usaha agribisnis perdesaan di kabupaten bogor. Jurnal KMP. 12(2): 8090. 